\title{
Fracture of Skull Related to Birth
}

National Cancer Institute

\section{Source}

National Cancer Institute. Fracture of Skull Related to Birth. NCI Thesaurus. Code C101318.

An injury sustained during the birthing process in which the continuity is broken in the skull. 